\title{
Herbs as a source of nutrition for flower-visiting hoverflies (Diptera, Syrphidae)
}

\author{
Elżbieta Wojciechowicz-Żytko*, Beata Jankowska
}

Department of Plant Protection University of Agriculture in Kraków 29 Listopada 54, 31-425 Kraków, Poland

\begin{abstract}
During two seasons of observations, 244 specimens of hoverflies belonging to 16 species and four trophic groups were collected from herb flowers. Predatory species constituted about $50 \%$ of all the registered species and from $55 \%$ (2010) to 64\% (2011) of all the specimens found. The most numerous flower-visiting species within this group were small, poor flyers, typical of communities with low plants - Sphaerophoria scripta (Linnaeus 1758) (19.6\% in 2010 and 23.5\% in 2011) and Eupeodes corollae (Fabricius 1794) (13.4\% and 12.1\%, respectively). Both species were classified to the eudominant group. Syrphus vitripennis (Meigen 1822) and Melanostoma mellinum (Linnaeus 1758) were classed as dominants. Non-predatory saprophagous species from the subfamily Eristalinae constituted about $25 \%$ of all collected species; the phytophagous group was scarce represented by Eumerus funeralis (Meigen 1822), E. strigatus (Fallen 1817) and Merodon rufus (Meigen 1838). Of the coprophagous species, only Syritta pipiens (Linnaeus 1758 ) was collected (6.8-8.0\%). There were clear differences between flowers in terms of feeding visits by adult hoverflies. Matricaria chamomilla L. and Thymus vulgaris L. were the most attractive flowers, whereas Origanum vulgare L., Carum carvi L., Lavandula angustifolia L. and Hyssopus officinalis L. were of an intermediate visit status and Ocimum basilicum L. was relatively under-visited.
\end{abstract}

Key words: attractiveness, blooming, flowering, nectar, syrphids

\section{INTRODUCTION}

Monocultures do not provide the floral resources for natural enemies (Rusch et al. 2010). Nectar and pollen producing food plants are usually scarce in homogeneous crops so establishment of flower strips has been suggested. Attracting beneficial insects by growing flowering plants as strips or field margins, or plots intercropped with flowers is considered an effective method of plant protection for integrated, and in particular organic, farming (Colley and Luna 2000). In this method, different aspects of the interaction between organisms in ecosystems are used, thus limiting the harmful human interference in the environment, especially the use of chemicals. According to Cowgill et al. (1993), some naturally growing plants on field margins are a good source of nutrition for flowervisiting hoverflies. An increase in food resources could offer a good opportunity for attracting beneficial insects and stabilizing their populations at high densities, and, as a consequence, contribute to the biological control of pests. Aromatic flowering herbs attract predatory insects, and also contain volatile oils which can conceal the host plant location and disturb the feeding, distribution

\footnotetext{
*Corresponding author.

Tel.: +48 126625376 ;

e-mail: ewojcie@ogr.ur.krakow.pl (E. Wojciechowicz-Żytko).
} 
and mating of pests, resulting in a decrease in their abundance (Finch and Collier 2000, Lu et al. 2007). They are also a valuable source of leaves and flowers for use in herbal medicine and in the kitchen.

A wide range of hoverfly species occurring near agrarian fields plays an important role in regulating agroecosystems. Syrphid adults pollinate flowers, their larvae live in varied conditions - their trophic habits are diversified. They are divided into a few trophic groups. A large part of them are saprophagous and herbivorous species, some feed in the nests of social insects (bumblebee, ant). The most important and largest group is comprised of predators which reduce the populations of aphids (Bańkowska 1963, van Veen 2004).

Floral resources are very important for the growth, development, survival and reproduction, and therefore the efficiency of Syrphidae and other predatory and parasitic insects. As a source of nectar and pollen, plants should be selected for a wide range of advantages e.g. agronomic and economic values, and attractiveness to beneficial insects. The use of herbicides reduces the biodiversity of flowering weeds, so introducing flowering plants (herbs) in the vicinity of fields or orchards would be the best way to increase the population of natural enemies (Hurej et al. 1998, Altieri 1999, Kienegger et al. 2003, Wojciechowicz-Żytko and Wnuk 2012).

The aim of this study was to evaluate the relative attractiveness (the best source of nutrition) of selected flowering herbs to adult syrphids, as well as to identify the species composition of flowervisiting Syrphidae.

\section{MATERIAL AND METHODS}

The experiment was carried out in 2010 and 2011 in the Herb Collection of the Faculty of Biotechnology and Horticulture $\left(50^{\circ} 08^{\prime} \mathrm{N}, 1^{\circ} 95^{\prime} \mathrm{E}\right)$ in Kraków. Adult individuals of the family Syrphidae were collected using a sweeping net, on sunny days, from May to August. Samples were collected for 15 min. (each sample) on $1 \mathrm{~m}^{2}$ plots of nine flowering herbs (Carum carvi L., Hyssopus officinalis L., Lavandula angustifolia L., Matricaria chamomilla L., Mentha piperita L., Ocimum basilicum L., Origanum vulgare L., Thymus pulegioides L. and Thymus vulgaris L.). Weekly observations were made on each plot of flowers in bloom between 10.00 and 12.00 o'clock because this is the time of peak daily activity of syrphids. Preferences for flowering plants were assessed by collecting the flies entering the plot and feeding on the flowers. Plants were considered to be in bloom when
$>50 \%$ of their flowers were opened. A relatively small plot size was used for the flower treatments because the goal of the experiment was to evaluate the attractiveness of randomly arranged flowers to syrphids in a free-choice feeding environment. The collected syrphids were identified using the keys developed by Bańkowska (1963) and van Veen (2004). The dominance of species was determined on the basis of their percentage by adopting the following classes: eudominants (ED) above $10.0 \%$; dominants (D) 5.1-10.0\%; subdominants (SD) 2.1 $-5.0 \%$; recedents (R) $1.1-2.0 \%$, and subrecedents (SR) less than 1.1\% (Dickler 1968).

\section{RESULTS AND DISCUSSION}

During the two seasons of observations, 244 specimens of hoverflies belonging to 16 species were collected from herb flowers (Tab. 1). Among the species, syrphids from 4 trophic groups (2 subfamilies) were caught. The subfamily Syrphinae - particularly important, as it consists of predatory species feeding mostly on aphids - constituted about $50 \%$ of all the registered species, and from $55 \%$ (2010) to $64 \%$ (2011) of all the specimens found (Tab. 1, Fig. 1). The collected syrphid species included Sphaerophoria scripta (Linnaeus 1758), Sphaerophoria interrupta (Fabricius 1805), Episyrphus balteatus (De Geer 1776), Syrphus vitripennis (Meigen 1822), Eupeodes corollae (Fabricius 1794), Melanostoma mellinum (Linnaeus 1758), Xanthogramma pedissequum (Harris 1776), Scaeva pyrastri (Linnaeus 1758). The most numerous flower-visiting species within this group were small, poor flyers, typical of communities with low plants $-S$. scripta $(19.6 \%$ in 2010 and $23.5 \%$ in 2011$)$ and E. corollae (13.4\% and $12.1 \%$, respectively). Both species were classified to the eudominant group. S. vitripennis and $M$. mellinum were found to be dominants. E. balteatus, very common in aphid colonies on trees and shrubs, was not numerous and was classified in 2010 year to recedents (Tab. 1). Kelm et al. (2009), in a study on the insect fauna visiting the flowers of 12 species of herbal plants, recorded a total of 194 specimens of the subfamily Syrphinae. The dominant species was S. scripta. Kienegger at al. (2003), studying the strips of wild flowers cultivated with broccoli, noted the most abundant occurrence of members of the genus Sphaerophoria - they constituted $85 \%$ of all individuals belonging to the aphidophagous subfamily Syrphinae (6 species). Colley and Luna (2000), investigating the attractiveness of 11 flowering plant species to 
Table 1. Number, percentage, dominant class and trophic groups of syrphids collected from flowers in 2010-2011

\begin{tabular}{|c|c|c|c|c|c|c|c|c|c|}
\hline \multirow[b]{2}{*}{ Species } & \multicolumn{3}{|c|}{2010} & \multicolumn{3}{|c|}{2011} & \multirow[b]{2}{*}{ Total } & \multirow[b]{2}{*}{$\%$} & \multirow{2}{*}{$\begin{array}{l}\text { Trophic } \\
\text { groups }\end{array}$} \\
\hline & Number & $\%$ & $\begin{array}{l}\text { Dominant } \\
\text { class }\end{array}$ & Number & $\%$ & $\begin{array}{l}\text { Dominant } \\
\text { class }\end{array}$ & & & \\
\hline \multicolumn{10}{|l|}{ Syrphinae } \\
\hline $\begin{array}{l}\text { Sphaerophoria scripta } \\
\text { (Linnaeus 1758) }\end{array}$ & 22 & 19.6 & $\mathrm{Ed}$ & 31 & 23.5 & $\mathrm{Ed}$ & 53 & 21.7 & Z \\
\hline $\begin{array}{l}\text { Sphaerophoria interrupta } \\
\text { (Fabricius 1805) }\end{array}$ & - & - & & 4 & 3.0 & $\mathrm{Sd}$ & 4 & 1.6 & Z \\
\hline $\begin{array}{l}\text { Episyrphus balteatus } \\
\text { (De Geer 1776) }\end{array}$ & 2 & 1.8 & $\mathrm{R}$ & 4 & 3.0 & $\mathrm{Sd}$ & 6 & 2.5 & Z \\
\hline $\begin{array}{l}\text { Syrphus vitripennis } \\
\text { (Meigen 1822) }\end{array}$ & 7 & 6.3 & $\mathrm{D}$ & 13 & 9.8 & $\mathrm{D}$ & 20 & 8.2 & Z \\
\hline $\begin{array}{l}\text { Eupeodes corollae } \\
\text { (Fabricius 1794) }\end{array}$ & 15 & 13.4 & $\mathrm{Ed}$ & 16 & 12.1 & $\mathrm{Ed}$ & 31 & 12.7 & Z \\
\hline $\begin{array}{l}\text { Melanostoma mellinum } \\
\text { (Linnaeus 1758) }\end{array}$ & 13 & 11.6 & $\mathrm{Ed}$ & 12 & 9.1 & $\mathrm{D}$ & 25 & 10.2 & Z \\
\hline $\begin{array}{l}\text { Scaeva pyrastri } \\
\text { (Linnaeus 1758) }\end{array}$ & 2 & 1.8 & $\mathrm{R}$ & 5 & 3.8 & $\mathrm{Sd}$ & 7 & 2.9 & Z \\
\hline $\begin{array}{l}\text { Xanthogramma pedissequum } \\
\text { (Harris 1776) }\end{array}$ & 1 & 0.9 & $\mathrm{Sr}$ & - & - & & 1 & 0.4 & Z \\
\hline \multicolumn{10}{|l|}{ Eristalinae } \\
\hline $\begin{array}{l}\text { Syritta pipiens } \\
\text { (Linnaeus 1758) }\end{array}$ & 9 & 8.0 & $\mathrm{D}$ & 9 & 6.8 & $\mathrm{D}$ & 18 & 7.4 & K \\
\hline $\begin{array}{l}\text { Eumerus funeralis } \\
\text { (Meigen 1822) }\end{array}$ & 1 & 0.9 & $\mathrm{Sr}$ & - & - & & 1 & 0.4 & $\mathrm{~F}$ \\
\hline $\begin{array}{l}\text { Eumerus strigatus } \\
\text { (Fallen 1817) }\end{array}$ & 5 & 4.5 & $\mathrm{Sd}$ & 3 & 2.3 & $\mathrm{Sd}$ & 8 & 3.3 & $\mathrm{~F}$ \\
\hline $\begin{array}{l}\text { Merodon rufus } \\
\text { (Meigen 1838) }\end{array}$ & 6 & 5.4 & $\mathrm{D}$ & 8 & 6.1 & $\mathrm{D}$ & 14 & 5.7 & $\mathrm{~F}$ \\
\hline $\begin{array}{l}\text { Eristalis tenax } \\
\text { (Linnaeus 1758) }\end{array}$ & 12 & 10.7 & Ed & 8 & 6.1 & $\mathrm{D}$ & 20 & 8.2 & S \\
\hline $\begin{array}{l}\text { Eristalis pertinax } \\
\text { (Scopoli 1763) }\end{array}$ & 5 & 4.4 & $\mathrm{Sd}$ & 3 & 2.3 & $\mathrm{Sd}$ & 8 & 3.3 & S \\
\hline $\begin{array}{l}\text { Helophilus pendulus } \\
\text { (Linnaeus 1758) }\end{array}$ & 8 & 7.1 & $\mathrm{D}$ & 11 & 8.3 & $\mathrm{D}$ & 19 & 7.8 & S \\
\hline $\begin{array}{l}\text { Myathropa florea } \\
\text { (Linnaeus 1758) }\end{array}$ & 4 & 3.6 & $\mathrm{Sd}$ & 5 & 3.8 & $\mathrm{Sd}$ & 9 & 3.7 & S \\
\hline Total & 112 & 100.0 & & 132 & 100.0 & & 244 & 100.0 & \\
\hline
\end{tabular}

$\mathrm{Z}$ - zoophagous, $\mathrm{S}$ - saprophagous, $\mathrm{F}$ - phytophagous, $\mathrm{K}$ - coprophagous, Ed - eudominants, $\mathrm{D}$ - dominants, $\mathrm{Sd}$ - subdominants, $\mathrm{R}$ - recedents, $\mathrm{Sr}$ - subrecedents

aphidophagous syrphidae, collected 12 species of hoverflies. The most common were Scaeva pyrastri, Sphaerophoria sulfuripes and the genus Toxomerus. Non-predatory saprophagous species of the subfamily Eristalinae constituted about $25 \%$ of all collected species, including Eristalis tenax (Linnaeus 1758), Eristalis pertinax (Scopoli 1763), Helophilus pendulus (Linnaeus 1758) and Myathropa florea (Linnaeus 1758), and from $20.5 \%$ (2011) to $25.8 \%$ (2010) of all the flies collected from flowers (Tab. 1, Fig. 1). In both years of observations, the most numerous were E. tenax (6.1-10.7\%) and $H$. pendulus (7.1-8.3\%). The phytophagous hoverflies, whose larvae feed inside the bulbs of vegetables and ornamental plants were scarce epresented by Eumerus funeralis Meigen, 1822, Eumerus strigatus (Fallen 1817) and Merodon rufus Meigen, 1838. Of the coprophagous species, only Syritta pipiens (Linnaeus 1758) was collected (6.8-8.0\%). In both years of observations, the proportion of the trophic groups was similar (Tab. 1, Fig. 1). 
2010

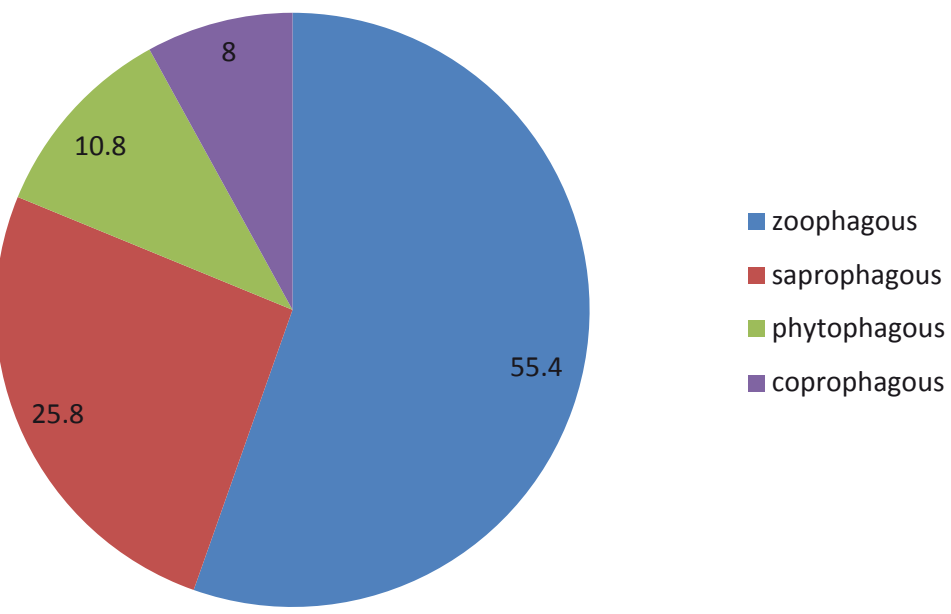

2011

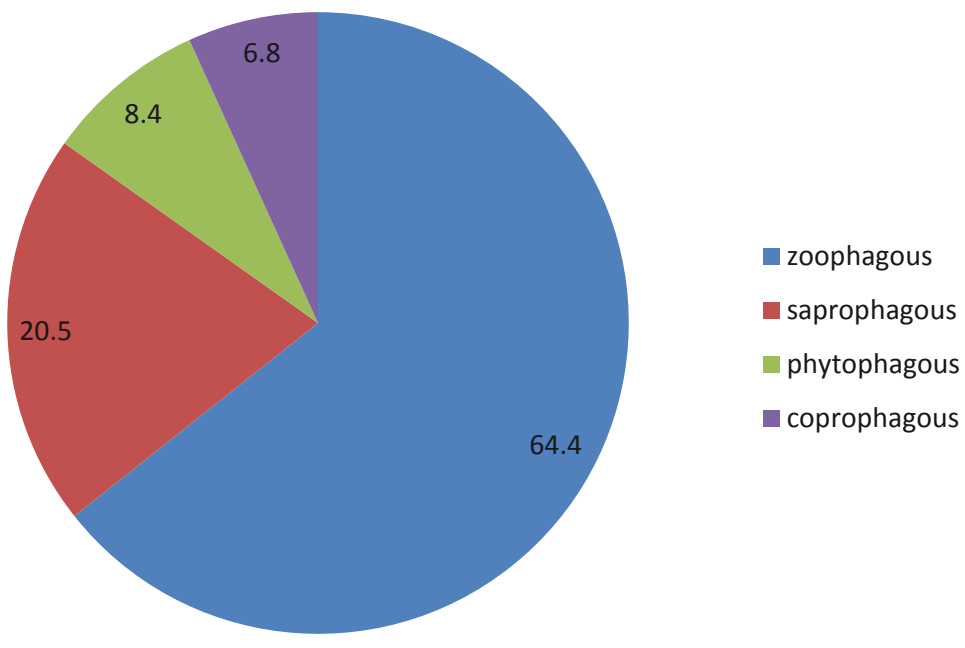

Figure 1. Trophic groups of Syrphidae

The time of flowering of the different herbs varied. M. chamomilla and T. vulgaris bloomed from early summer to early autumn (3-4 months), whereas L. angustifolia, H. officinalis, M. piperita and $O$. basilicum bloomed in midsummer (Tab. 2).

There were clear differences between flowers in terms of feeding visits by adult hoverflies; however, the collected syrphids did not exhibit floral constancy (Tab. 2, Fig. 2). Matricaria chamomilla L. and Thymus vulgaris L. were visited relatively frequently (7.4 and 7.3 specimens per sample, respectively), whereas Origanum vulgare L., Carum carvi L., Lavandula angustifolia L., and Hyssopus officinalis L. were of an intermediate visit status and Ocimum basilicum L. was relatively under-visited. M. chamomilla and T. vulgaris were visited more frequently than any other flowers, but their attractiveness was not constant throughout the season. On the first sampling dates, M. chamomilla was the most preferred flower, but on the last ones $T$. vulgaris was highly attractive to syrphids. During the study, Aphis fabae Scop. colonies were observed on M. chamomilla. According to Chandler (1968), the presence of aphids on flowers could attract gravid hoverfly females, potentially increasing feeding visits.

Sadeghi (2008), assessing the attractiveness of 16 species of flowering plants to hoverflies, found that Cosmos bipinnatus, Petuniajuss and Matricaria chamomilla were visited more frequently than other floral sources. According to Kelm et al. (2009), the greatest abundance of Syrphidae was observed on the flowers of Lamiaceae (Mentha piperita, Nepeta cataria and Thymus vulgaris). The flowers of Hyssopus officinalis and Oreganum vulgare seem to be slightly less attractive to the visiting flies. Also Hurej at al. (1998) studying weedy strips observed syrphid adults mainly on the flowers of M. chamomilla. All of the above-mentioned authors emphasize the high attractiveness of $M$. chamomilla and T. vulgaris flowers to syrphids. According to Sajjad and Saeed (2010), and Jankowska (2012), among early-season flowering plants Coriandrum sativum (L.), and among late-season Achillea 
Table 2. The occurrence of syrphids on herb flowers (2010-2011)

\begin{tabular}{|c|c|c|c|c|c|c|c|c|}
\hline \multirow{2}{*}{ Species } & \multirow{2}{*}{$\begin{array}{l}\text { Time of } \\
\text { flowering }\end{array}$} & \multicolumn{2}{|c|}{2010} & \multicolumn{2}{|c|}{2011} & \multirow{2}{*}{ Total } & \multirow{2}{*}{$\%$} & \multirow{2}{*}{$\begin{array}{l}\text { Number per } \\
\text { sample }\end{array}$} \\
\hline & & Number & $\%$ & Number & $\%$ & & & \\
\hline Matricaria chamomilla $\mathrm{L}$. & VI-VIII & 25 & 22.3 & 34 & 25.8 & 59 & 24.1 & 7.4 \\
\hline Thymus vulgaris $\mathrm{L}$. & VI-IX & 19 & 17.0 & 39 & 29.5 & 58 & 23.8 & 7.3 \\
\hline Origanum vulgare L. & VII-IX & 19 & 17.0 & 15 & 11.4 & 34 & 13.9 & 4.3 \\
\hline Carum carvi L. & V-VI & 12 & 10.7 & 10 & 7.5 & 22 & 9.0 & 2.8 \\
\hline Lavandula angustifolia $\mathrm{L}$. & VII-VIII & 9 & 8.0 & 10 & 7.5 & 19 & 7.8 & 2.4 \\
\hline Hyssopus officinalis L. & VII-VIII & 12 & 10.7 & 5 & 3.8 & 17 & 7.0 & 2.1 \\
\hline Thymus pulegioides L. & VI-VII & 9 & 8.0 & 6 & 4.6 & 15 & 6.1 & 1.9 \\
\hline Mentha piperita $\mathrm{L}$. & VII-VIII & 5 & 4.5 & 7 & 5.3 & 12 & 4.9 & 1.5 \\
\hline Ocimum basilicum $\mathrm{L}$. & VII-VIII & 2 & 1.8 & 6 & 4.6 & 8 & 3.4 & 1.0 \\
\hline Total & & 112 & 100.0 & 132 & 100.0 & 244 & 100.0 & \\
\hline
\end{tabular}

millefolium (L.). Foeniculum vulgare (Miller) and Agastache rugosa (Fischer \& C.A. Meyer) (Colley and Luna 2000) were the most attractive to syrphid adults. Cowgill et al. (1993) found that some naturally growing plants on field margins are a good source of nutrition for flower-visiting hoverflies. The beneficial effect of phacelia flowers in attracting syrphids was noted by Lovei et al. (1992), Hickman and Wratten (1996) and Wnuk at al. (2009).

Although herbs do not seem to be a very attractive habitat for the Syrphidae, they play an important role as a source of additional food for adult individuals. The flowers of herbs could attract syrphids to crops and thereby entice them to lay eggs in the aphid colonies occurring on the growing crop plants. Observations on the role of flowering plants in the occurrence of syrphids have shown an increase in oviposition within the field surrounded by flowering plants and a decrease in aphid populations (Kienegger et al. 2003). The authors noted that the eggs and larvae of hoverflies tended to be more abundant in plots with flowers than in control plots.

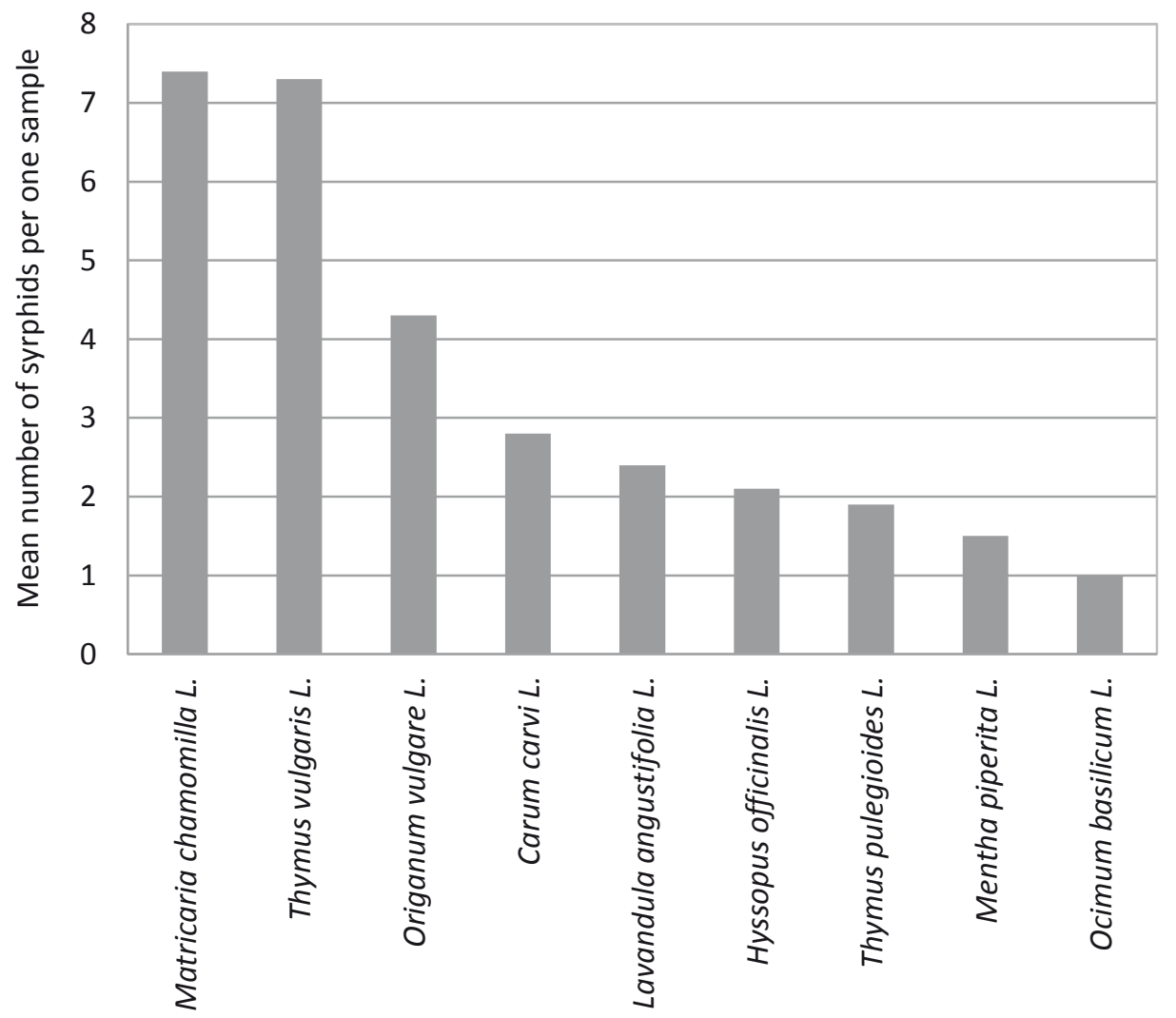

Figure 2. Mean number of syrphids collected from different flowers (per one sample) 
Attractiveness of floral sources to beneficial insects is an important initial consideration, but the candidate plant species should be screened for a wide range of attributes, including their economic and agronomic compatibility with the crop plants, as well as their impact on the fecundity and longevity of beneficial insects.

Aromatic herbs, except the flowers which attract beneficial insects, contain volatile oils which can conceal the host plant location and disturb the feeding, distribution and mating of pests, resulting in a decrease in their abundance (Finch and Collier 2000, Lu et al. 2007). They are also a valuable source of leaves and flowers for use in herbal medicine and in the kitchen.

Many authors have highlighted the importance of habitats rich in flourishing vegetation for Syrphidae (Wnuk et al. 2009, Jankowska and WojciechowiczŻytko 2011).

Several studies have demonstrated that the diversification of agroecosystems by using the strategy of companion planting may reduce insect pest infestation (Cowgill et al. 1993, Altieri 1999, Kienegger et al. 2003, Wojciechowicz-Żytko and Wnuk 2012). Establishing flowering plants in and around crop fields may be classified as a proecological method limiting the harmful human interference in the environment, especially the excessive consumption of chemicals. Diversity in landscape structures influences ecosystem services provided by insects by supporting generalist predators and parasitoids (Hurej et al. 1998, Altieri 1999, Wiech et al. 2009).

\section{CONCLUSIONS}

1. The predatory species of Syrphidae constituted about $50 \%$ of all the registered species. The most numerous species were Sphaerophoria scripta and Eupeodes corollae.

2. There were clear differences between flowers in terms of feeding visits by adult hoverflies; however, the collected syrphids did not exhibit floral constancy.

3. Matricaria chamomilla L. and Thymus vulgaris L. were the most attractive flowers to Syrphidae. It seems that they were the best source of nutrition for hoverfly adults.

4. Flowering herbs growing in the vicinity of horticultural crops could attract syrphids and thereby entice them to lay eggs in the aphid colonies occurring on the growing plants.

\section{FUNDING}

This research was supported by the Ministry of Science and Higher Education of Poland as part of the statutory activities of the Department of Plant Protection of the University of Agriculture (DS-3500/WBiO).

\section{AUTHOR CONTRIBUTIONS}

Both authors contributed equally to this work. E.W.Z. and B.J. - designed and performed the experiments, analyzed the data and wrote the paper.

\section{CONFLICT OF INTEREST}

Authors declare no conflict of interest.

\section{REFERENCES}

Altieri M.A., 1999. The ecological role of biodiversity in agroecosystems. Agric. Ecosyst. Environ. 74: 1931.

BaŃkowsKa R., 1963. Syrphidae. In: Klucze do oznaczania owadów Polski, z. 28. Diptera 34. PWN, Warszawa, Poland.

Chandler A.F.F., 1968. Some host-plant factors affecting oviposition by aphidophagous Syrphidae (Diptera). Ann. App. Biol. 61: 415-423.

Colley M.R., LunA J.M., 2000. Relative Attractiveness of Potential Beneficial Insectary Plants to Aphidophagous Hoverflies (Diptera: Syrphidae). Environ. Entomol. 29(5): 1054-1059.

Cowgill S.E., Wratten S.D., Sotherton N.W., 1993. The selective use of floral resources by the hoverfly Episyrphus balteatus (Diptera: Syrphidae) on farmland. Ann. Appl. Biol. 122: 223-231.

DiCler E., 1968. Untersuchungen zur Besiedlung von wiesennahen Leguminosenkulturen durch Rüsselkäfer. Zeit. f. angew. Ent. 55: 129-192.

Finch S., Collier R.H., 2000. Host-plant selection by insects-a theory based on "appropriate/inappropriate landings" by pest insects of cruciferous plants. Entomol. Exp. Appl. 96: 91-102.

Hickman J.M., Wratten D., 1996. Use of Phacelia tanacetifolia strips to enhance biological control of aphids by hoverfly larvae in cereal fields. J. Econ. Entomol. 89: 832-840.

Hurej M., KróL J., TwardowsKi J., 1998. Attraction of aphid predators by cultivated and weedy strip. Aphids and Other Homopterous Insects. PAS 6: 117124.

JANKOWSKAB.,2012.Wpływwybranychniechemicznych sposobów ochrony warzyw kapustowatych na szkodliwą i pożyteczną entomofaunę. Zesz. Nauk. UR w Krakowie 491(368). Ph.D. dissertation, University of Agriculture in Kraków, Poland, 131 p.

Jankowska B., Wojciechowicz-Żytko E., 2011. The occurrence of hoverflies (Syrphidae) on flowers in 
the Botanic Garden of the Jagiellonian University in Krakow. Aphids and Other Hemipterous Insects 17: 157-166.

Kelm M., Biesiada A., KrawczyK M., Ciolek M., 2009 Atrakcyjność kwiatów wybranych roślin zielarskich dla mszycożernych bzygowatych (Syrphinae). Zesz. Probl. Post. Nauk Roln. 539: 307-311.

Kienegger M., Kromp B., Kahrer A., 2003. The effect of strips of flowers on pests and beneficial arthropods in adjacent broccoli plots. IOBC Bull. 26(3): 61-69.

Lovei G.L., McDougall D., Bramley G., Hodgson D.J., Wratten S.D., 1992. Floral resources for natural enemies: the effect of Phacelia tanacetifolia (Hydrophyllaeae) on within-field distribution of hoverflies (Diptera: Syrphidae). Proc. $45^{\text {th }}$ N. Z. Plant Prot. Conf.: 60-61.

Lu W., Hou M.L., WeN J.H., Li J.W., 2007. Effects of plant volatiles on herbivorous insects. Plant Protection 33: 7-11.

Rusch A., Valantin-Morison M., SARthou J.P., RogerEstrade J., 2010. Biological control of insect pests in agroecosystems. Effects of crop management, farming systems, and semi-natural habitats at the landscape scale: a review. Adv. Agron. 109: 219-259.

SADEGHI H., 2008. Abundance of adult hoverflies (Diptera: Syrphidae) on different flowering plants. Caspian J. Environ. Sci. 6(1): 47-51.
SajJad A., SAeEd S., 2010. Floral host plant range of syrphid flies (Syrphidae. Diptera) under naturae conditions in Southern Punjab. Pakistan. Pak. J. Bot. 42(2): 1187-1200.

van VeEn M.P., 2004. Hoverflies of Northwest Europe. Identification keys to the Syrphidae. KNVV Publishing.

WIEchK.,WnUkA.,WoJCIECHOWICZ-ŻYTKoE.,JANKOWSKA B., 2009. Wpływ infrastruktury ekologicznej na agrofagi i organizmy antagonistyczne w uprawach warzyw. Prog. Plant Prot. / Post. Ochr. Roślin 49(3): 1124-1132.

WNuk A., WoJciechowicz-Żytko E., Waligóra U., 2009. Atrakcyjność kwiatów facelii błękitnej (Phacelia tanacetifolia Benth) w przywabianiu mszycożernych bzygowatych (Diptera. Syrphidae). Zesz. Probl. Post. Nauk Roln. 539: 743-751.

Wojciechowicz-Żytкo E., Wnuk A., 2012. The occurrence of Syrphidae in Aphis fabae Scop. (Hemiptera) colonies on broad bean intercropped with phacelia (part II). J. Plant Prot. Res. 52(2): 246251.

Received April 20, 2016; accepted February 3, 2017 